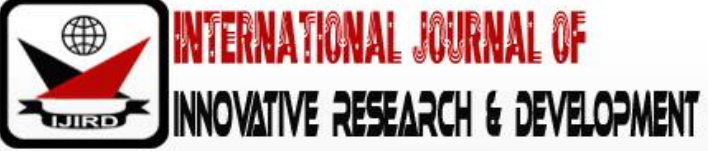

ISSN 2278 - 0211 (Online)

\section{Kenya and the Blue Economy: The Way Ahead}

\author{
Dr.John O.Kakonge \\ President, Association of Former International Civil Servants of the United Nations, Kenya
}

\begin{abstract}
:
With its myriad inland lakes, rivers and thousand-mile coastline, Kenya stands to gain immensely from the "blue economy" - in other words, its immense and abundant water resources. For this to happen, however, numerous challenges need to be overcome. The very notion of the blue economy must be understood by Kenyans of all socioeconomic classes, while efforts are made to surmount capacity shortages, lack of funds, and inadequate research and innovation. Only then can any forward movement be contemplated. Mainstreaming the blue economy into the national development plan Vision 2030; establishing partnerships locally, regionally and internationally; devising innovative ways of raising funds through local, external and public-private initiatives, and placing emphasis on research and education will all help in this regard. Above all, the Kenyan government needs to prioritize the blue economy and engage with all stakeholders, including local communities, national and county governments, research institutions, politicians, the private sector and others. As Ankomah (2018) warns, Kenya should understand that implementing development activities under the blue economy must not be viewed as business as usual.
\end{abstract}

Keywords: Blue economy, addressing challenges, partnerships, mainstreaming

\section{Introduction}

With Lake Victoria to the west, Lake Turkana in the north, and the Indian Ocean forming the south-eastern boundary of the country, Kenya is well situated to benefit from the development of its blue economy. Numerous challenges, however, combined with a lack of clarity regarding what exactly is the blue economy, are holding back development of this important sector.

This article identifies the key challenges that Kenya is facing in its endeavour to develop its blue economy, namely, the need clearly to define and adopt the new concept;a lack of capacity in expertise to implement the concept;insufficient funds; and a lack of research and innovation. The article concludes with suggestions for the way forward.

\section{Defining the Blue Economy}

The concept of the blue economy is complex and needs to be further articulated. Many scholars offer varying explanations of the subject, resulting in a lack of consensus. For instance, Hancock (2017) notes that the terminology is confusing with numerous synonyms in play and many related terms which are used interchangeably.Of these, the most common synonyms are "ocean economy", "marine economy", "marine sector"and"maritime sector".

Reaching agreement on the precise scope and substance of the blue economy is of critical importance in guiding interactions in this domain between different countries and between their public and private sectors.Understandably, therefore, the Economist Intelligence Unit (EIU, 2015) has cautioned that the notion of blue economy remains ill-defined and open to wide, and often different, interpretations.

For the purpose of this article,the Commonwealth Secretariat's broad definition is adopted, namely"blue economy is an emerging concept which encourages better stewardship of our oceans or 'blue' resources." This definition is the most appropriate since it is aligned with economic growth and thelong-term health of the oceans.

The concept of the blue economy has yet to be mainstreamed and integrated into Kenya'sVision 2030. While most people are familiar with the concept of the green economy,they have yet to adopt the blue economy. For many years, the blue economy has largely covered the same areas as the green economy and the terms have been treated as synonyms, which may havecontributed to the ambiguity in trying to define it. As Benkenstein (2018) notes, the blue economy in Kenya cuts across various sectors and stakeholders and requires coordination and buy-in across numerous vertical and horizontal axes.

To facilitate the integration of the concept, Kenya established a Blue Economy Implementation Committee chaired by the Kenya DefenceForce, composed of the principal secretaries from the departments of fisheries; maritime and shipping affairs; the national treasury; transport, and the environment. This committee was mainly intendedto support the planning and organization of the internationalSustainable Blue Economy Conferencewhich was held at the end of November 2018 in Nairobi.

The government of Kenya has yet to come up with anyfollow-up activitiessince the conference. Moreover, from the beginning, there was limited public communication about the precise mandates and priorities of the national Blue 
Economy ImplementationCommittee.Furthermore, the government has notput forward a new and realistic strategic plan for the blue economy or policies to rolloutthe blue economy in the country.

\section{Lack of Capacity}

Given that the blue economy includes both offshore and land-based water resources, Kenya lacks a critical mass of expertise in the water and land-use sectors to assess and monitor activities, such as, for example, pollution in catchment areas which have anegative impact on rivers, lakes and aquifers.Besides, there is a severe shortage of agricultural extension staff who could help educate farmers to minimize the use of fertilizers and pesticides which drain into the major rivers,such as the Nzoia, Nyando, Kuja, Tana-Athi, Yala and others. For example, most of the flamingos in Lake Nakuru have disappeared as a consequence of ignorance of sustainable agricultural practices. At the coastal area, Kenya lacks maritime expertise and offshore engineers in technology and infrastructure.

In short, Sagar (2017), quoting the chief executive of the Maritime and PortAuthority of Singapore, Andrew Tain, confirmed that the principal requirement of all countries wishing to develop a blue economyis an integrated approach bringing together science, research, technology and multiple relevant disciplines, to understand the various eco-systems within the oceans and the link between land and sea and how each affects the other. This is lacking in Kenya.

\section{Lack of Funds for the Blue Economy}

Until recently, the blue economy has been dominated by governments;now, however,the private sector is showing more interest (Whisnant, 2015). After the Sustainable Blue Economy Conferencein Nairobi in late 2018, it became clear that to translateand implement the recommendations of that conference, strong financial partnerships amongbusiness, governments, donors, NGOs, foundations,and othersarerequired.Examples where these types of partnerships are already supporting blue economy initiatives includecollaboration between governments and businesses such as IBM andAPTWaterin the USA;TOKADUin Israel, and Aquaz and Ustrara in Canada (Henderson \& Parker, 2012). These companies have all taken leadership in financing and creating new platforms forinnovation in watershed, seawater and drinking watermanagement.

One of the challenges that Kenya is facing currently is a lack of funds to meet all its priorities under Vision 2030, besides the current four national priority pillars of President Uhuru Kenyatta.

As Muigua (2018) notes, the Nairobi Sustainable Blue Economy Conference pledged numerous voluntary nonmonetary and monetary commitments amounting to some $\$ 172.2$ billion in the various sectors of the blue economy. Kenya shouldnot only capitalize on thesepledgedresources but should also devise its own realistic national blue economy plan with a proposed budget, to solicit both local and external funding.

\section{Lack of Research and Innovation}

To exploit all areas of the blue economy, and in particular those pertaining to its marinedimension, requires intensive research and innovation. Several advanced countries with coastal lines and water masses are currently involved in innovative research. Unfortunately, in Kenya, research is not considered a national priority and thereforedoesnot receive a large financial allocation. The little money that is allocated for research is insufficient to share around. Sadly, over the last two decades, external assistance in research has also declined. In fact, some African countries have categorically insisted that donors should not allocate money for research. Rather, they haverequested fundingforthe implementation of projects. If any researchis undertaken, it is in the form of baseline studies built into the approved project budgets.

To add to the problem, and as noted by the KenyanAuditor General in his reports of the last three years, themoney allocated for research has been mismanaged with little evidence of its correct expenditure in the form of research reports. Even if there are funds for blue economy research, it is fragmented and scattered between and among many ministries, departments, institutions and county governments.

\section{Way Forward}

\subsection{Mainstreaming the Blue Economy into the National Agenda}

The main activitiesof a blue economy are associated with water. Henderson and Parker (2012) arguethat the blue economy needs to be fully mainstreamedwith the national development plans of African countries, Kenya included. In other words, every member of Kenyansociety should have a basic understanding of water systems in the country, in terms of rivers, lakes, aquifers and coastal areas. In particular, people need to appreciate that water is critical to the life of everyone in the country. According to Henderson and Parker(2012), the public needs to be brought on board to debunkthe notion that water is an abundant, unlimited resource. Accordingly, county and national governments, NGOs, and the private sector should work together to raise water literacy of everyone in the country. In short, Henderson and Parker (2012) emphasize that it is time to recognize the true value of water and itsimportanceto a global blue economy.

\subsection{Partnerships}

Henderson and Parker (2012) argue that, in a blue economy, no one can function in isolation. For that reason, the development of a blue economy calls for creative innovation between government, the private sector, research institutions, NGOs and communities. Simply put, to be successful, the blue economy requires creative partnerships which bring together diverse knowledge and the expertise necessary to address the increasing challenges of sustainable water use. 
Offshore activities that form part of the blue economy are complex. These include fishing, marine tourism, marine biotechnology, marine manufacturing, shipping, portand maritime logistics, marine construction, marine commerce, marine ICT and education and research. It would make sense for Kenya to seek partnerships with advanced countries or traditional donors and the private sector to gain assistance in the development of most of the activities listed above. For example, the government could explore partnerships with such countries as Norway, Poland and others, to enable the populations in Lamu and other Kenyan coastal towns to upgrade their skills in making medium-sized commercial fishing ships. In addition, Kenya should forge relations with emerging countries such as India and Seychelles which have madestrides in harnessing their blue economy, and with Singapore, which has an advanced blue economy. Fortunately, these countries have a great deal in common with Kenya: they are all members of the British Commonwealth and canuse the structures of the Commonwealth to share their experience and knowledge of their blue economies.

\subsection{Additional Resources}

Kenya will have to raise funds both locally and externally in order to carry out blue economy activities. Given that one of the objectives of a blue economy is to promote participation of the local people or communities, the government should devise programmes or projects to help local people scaleup their activities. For example, Seychelles has gone a step further by offering blue bonds (Worldfolio, 2019) to support the fisheries industry. In addition, Seychelles is attracting foreign direct investment. Kenya should perhaps consider offering blue bonds to boost its blue economy. Kenya should prioritize the blue economy by allocating a certain percentage of the national budget to support its development.In addition, it should consider implementing the Economist Intelligence Unit's(EIU 2015)advice that publicprivate partnershipsshould be pursued for some blue economy activities.

\subsection{Research and Education}

Research and educationare critical to the development of a blue economy. Governments need to come up with ways and means of raising money for research and education. In particular, the Kenyan government should designate blue economy institutions. Public universities should focus on teaching and researchonfreshwater and the marine sectors of the blue economy. Furthermore, Kenya should establish research collaborations with research centres within Africa that are currently involved in the blue economy. This will enhance the sharing of useful information and strengthenthe framework of South-South cooperation.

The European Union provides insight into the development of successful blue economies. For instance, according to Kaczynski (2011), the EU hasinvested in undersea sensor work, computer modelling, biological diagnostics, data archiving and international collaboration in oceanography research.Moreover,the EU is also targeting countries for networking which have done well in blue economy research,such as the USA, Japan, Canada, China, the Republic of Korea and others.

Interestingly, Seychelles, a developing country like Kenya,is doing well in the development of their blue economy and has prioritized relevant research, education and supporting citizen scientists. Anantha and Matataken (2015) acknowledge that citizen scientists in Seychelles collect useful quality data that is comparable to those collected by professional scientists. The investment of shareholders and the local communities in the blue economy is a win-win for the islands of the Seychelles. It therefore makes perfect sense that, to make progress in the blue economy, Kenya should likewise invest in research and education

\section{Summary} imperatives.

For Kenya to benefit from the blue economy the government has to give z\ serious consideration to the following

- The government should seriously prioritize development of its blue economy and consolidate its activities in that domain, which are currently fragmented. These activities should be integrated into a department of its own with a comfortable budget to carry out, among other things, the recommendations of the Sustainable Blue Economy Conference, as set out in the Nairobi Declaration of 2018. Given that fisheries form part of the blue economy, there is no need to have a separate Department of Fisheries. Consequently, this would allow the new Blue Economy Department to have the capacity needed for its modernization and to make it more responsive and effective. Barbados has implemented this approach and Kenya should follow suit.

- The Kenyan government should set aside funds to train a critical mass of specialists in all the key areas of the blue economy and fisheries. For instance, Kaczynski (2011) noted that the EU has invested in the education of young professionals of its member States in order to modernize and expand the maritime sector of the EU blue economy. This is what the government of Kenya should dourgently. Its colleges and universities should include programmes in blue education. In addition, following the example of Seychelles, the government should also introduce and support citizen science.

- According to the Nairobi Sustainable Blue Economy Conference, the blue economy should focus on adding value to existing activities. As an example of this, Seychelles is educating the local people in marketing and practical knowhow, thus widening the country's opportunity to take control of its destiny and enjoy the advantages of a blue economy (Worldfolio, 2019). Similarly, South Africa has introduced a development strategy known asOperation Phakisa,which prioritizes maritime skills and educationto attract public-private partnerships and international private investors (Rustomjee, 2018).

- The current artisanry activities being undertaken by local people and communities should be scaledup by the national government. Specifically,fisherfolkfrom Lake Turkana, Lake Victoria and along the coast should be assisted 
with modernized equipment such as refrigerators and deep-freezes to reduce post-harvest losses. In addition, the fishermen could beassisted by being given direct access to markets, with the removal of the middlemen who squeeze their profits. In this context, it is worth noting that, as indicated byMarete(2017), President Kenyatta'sban on foreign vessels at the Kenya coast was intended to boost local fish processingfrom its current level of 2,500 tons to 18,000 tons per year.

- Afew fish processing plantscould be built at specific major towns along Lake Victoria, Lake Turkana, and the coast. Local processing of the catch will minimize post-harvest losses, which in turn, will add value to the fishermen's products and will create related employment opportunities for local communities. The county governments and national government should engage with donors such asthe EU and others to determine whether theyshould fund these plants.

- With regard to offshore blue economy activities, scalingup or adding value will presentchallenges. Kenyan fishermen will need bigger vessels toexploit the deepwater of its continental shelf. Before the banning of foreign vessels in Kenyan waters by President Kenyatta, local fishermen were at a distinct disadvantage. Marete(2017) also revealsthat the former Police Inspector General launched boats not only to improve surveillance in the Indian Ocean, with a view to establishing a coast guard service, but also to encourage local fishing vesselsto venture deeper into the ocean.

- Other businesses should work closely with the Kenyan Navy toprotecttheir offshore activities,such asthe proposed mineral exploration. The Kenya government should forgepartnerships with oil and gas companies that may be interested in investing in offshore activities. Caution must be exercised in this undertaking, however, as this will come with many unknown environmental risks,the oil spills in the Gulf of Mexicobeing an instructive example in this regard. Regardless, the Kenya government shouldbuild expertise in robust environment impact assessment for offshore activities prior to the onset of commercial mining. This,in turn, will help to ensure effective stewardship and preservation of the marine environment.

\section{Conclusion}

Clearly, Kenya is not going to derive much benefit from the blue economy and its abundant potential if the country follows the business-as-usual approach. Already we can see many projects and programmes which have stalled owing to mismanagement or corruption. Moreover, as Ankomah(2018) notes, African countries, Kenya included, have not given serious attention to the development of the blue economy or to harnessing the potential of its seas. To take advantage of its blue economy and the immense potential which it offers, Kenya must prioritize those areas in which it hasa comparative advantage and where it can launch new projects or scaleup those already in existence. Research and innovation arevital to developing relevant experience and skills,in particular in offshore activities. This can be achieved through collaboration within Africa and with countries in other continents.

Those African countries which are making progress inharnessing the resources of their blue economy, principally South Africa, Mauritius, and Seychelles, have made robust efforts to involve their public and local communities in blue economy activities. The involvementof these sectors of the population ensures recognition across the entire society of the true value of the water resources in their country's rivers, lakes and seas. The Kenyan government should also create an enabling environment to support efforts by the private sector and small and medium-sized enterprisesto become key players in the blue economy, in particular in such areas as marine tourism, marine transport and commercial fishing, among many other opportunities. Above all, the government should mainstream the blue economy into its national agenda for the future: Vision 2030.

As theEconomist Intelligence Unit(EIU 2015) concludes:"The challenge remains of how to create predictable cash flows for investors behind the valuable ecosystem services offered by the oceans."Kenya should take inspiration from countries like Indonesia, whose blue economy contributes $20 \%$ of its GDP, and ensure that its own blue economy plays a comparably significant role in the Kenyan economy.

\section{*The views, thoughts and opinions expressed in this paper belong solely to the author and not necessarily to AFICS-Kenya.}

\section{References}

i. Anantha, S and Matatoken, D (2015). Best Practices for the development of the blue economy engaging stakeholders in ocean planning. Island Studies Journal, March 2015.

ii. Ankomah, B (2018). Africa's Blue Economy: What are the limits. New African Magazines. Nov. 2018. https:/ / newafricanmagazine.com/ 17681/ . Accessed 21 August 2019.

iii. Benkenstein, A (2018). Prospects for the Kenyan Blue Economy. SA11A, P. Key insights No. 62.

iv. EIU (2015). Economist Intelligence Unit: The Blue Economy: Growth,

v. Opportunity and a Sustainable Ocean Economy. https://www.greengrowthknowledge.org/ resource/ blueeconomy-growth-opportunity-and-sustainable-ocean-economy. Accessed 21 August 2019.

vi. Hancock, A (2017). Overview: investigating the blue economy: toward a statistical standard. United Nation Department of Economic and Social Affairs: Statistics Division. ESA/ STAT/ AC.340/ 17.

vii. Henderson, D and Parker, N (2012). The Blue Economy: Risks and Opportunities in Addressing the Global Water Crisis. 
http:/ / www.gordonfoundation.ca/ blue-economy.ca/ sites/ default/ files/ reports/ BlueEconomyInitiative\%20\%20WEB.pdf. Accessed 20 August 2019.

viii. Humphrey, K (2018). The unfolding story of Barbados's blue economy. http:// www2.intracen.org/ news/ Theunfolding-story-of-Barbadoss-blue-economy/ Accessed 21.Accessed 21 August 2019.

ix. Kacyzynski, W (2011). The Future of Blue Economy: Lessons for European Union. Foundations of Management, $3(1): 21-32$.

x. Marete, C(2017).Kenya Bans Foreign Trawlers to boost local sector.https:/ / www.theeastafrican.co.ke/ business/ Kenya-bans-foreign-trawlers-to-boost-local-sector-/ 25604236820-dvuuvkz/ index.html. Accessed 17 August 2019.

xi. Muigua, K (2018). Harnessing the blue economy challenges and opportunities for Kenya. http:// kmco.co.ke/ wpcontent/ uploads/ 2018/ 12/ Harnessing-the-Blue-Economy-Challenges-and-Opportunities-for-Kenya-24thDecember-2018.pdf.20. Accessed 20 August 2019.

xii. Rustomjee,C (2018). Green Shoots for the African Blue Economy? CIGI Policy Brief No. 132.

xiii. Sagar, M (2017). An Integrated Approach to a 'Blue Economy'. Open Gov. https:// www.opengovasia.com/anintegrated-approach-to-a-blue-economy/ . Accessed 21 August 2019.

xiv. The Worldfolio (2019). Blue economy pioneer sets global example. http:/ / www.theworldfolio.com/ news/ blueeconomy-pioneer-sets-global-example/ 4194/ . Accessed 18 August 2019.

xv. Whisnant, R (2015). Has the Blue Economy finally arrived for business? https://www.ecobusiness.com/ opinion/ has-the-blue-economy-finally-arrived-for-business/ . Accessed 17 August 2019. 